\title{
GROUNDWATER DROUGHT IN THE NITRA RIVER BASIN - IDENTIFICATION AND CLASSIFICATION
}

\author{
MIRIAM FENDEKOVÁ, MARIÁN FENDEK
}

Department of Hydrogeology, Faculty of Natural Sciences, Comenius University in Bratislava, Mlynská dolina, Pav. G, 84215 Bratislava; Mailto: fendekova@fns.uniba.sk

Drought as a natural phenomenon becomes more often the subject of the research. It is because of the increasing frequency of extreme climatic events also in mild climate conditions. Groundwater drought indices could be derived for different groundwater parameters, among them for base flow, groundwater head stage, spring yield, or groundwater recharge. Base flow drought assessment methods were proposed in the paper. Base flow values were separated from the discharge hydrograms using the new HydroOffice 2010 program package, lately developed by Gregor. The base flow drought severity index was applied, calculated as the value of the base flow drought deficit volume divided by the drought duration. After that, the standardized base flow drought severity index was proposed as the ratio of the base flow drought index and the average long-term annual base flow. Proposed methods were applied in the Nitra River basin. Base flow drought occurrence was characterized also from the seasonality point of view.

KEY WORDS: Drought, Groundwater Parameters, Cumulative Frequency Curve, Threshold Level Method, Standardized Base Flow Drought Severity Index, Nitra River Basin.

Miriam Fendeková, Marián Fendek: SUCHO V PODZEMNEJ VODE V POVODÍ TOKU NITRA IDENTIFIKÁCIA A KLASIFIKÁCIA. J. Hydrol. Hydromech., 60, 2012, 3; 28 lit., 4 obr., 6 tab.

Sucho ako jeden z prírodných javov sa čoraz častejšie stáva predmetom výskumu. Príčinou je narastajúca frekvencia výskytu extrémnych klimatických situácií aj v miernych zemepisných šírkach. Klasifikačné kritériá výskytu sucha v podzemnej vode možno odvodit' pre rôzne parametre podzemnej vody, napríklad pre hodnoty podzemného odtoku, úrovne hladiny podzemnej vody, výdatnosti prameňa alebo doplńania zásob. V príspevku sú navrhnuté metódy hodnotenia sucha v podzemnom odtoku. Hodnoty podzemného odtoku boli z hydrogramu prietokov odseparované pomocou nového štatistického balíka HydroOffice 2010, ktorý bol v nedávnej minulosti vytvorený Gregorom. Index závažnosti sucha bol vypočítaný ako podiel nedostatkového objemu podzemného odtoku a dížky trvania sucha. Následne bola hodnota indexu závažnosti sucha normalizovaná vydelením dlhodobou priemernou hodnotou podzemného odtoku. Navrhnutá metodika bola použitá pre povodie toku Nitra. Výskyt sucha v podzemnej vode bol hodnotený aj z pohl'adu jeho sezónnosti.

KLÚČOVÉ SLOVÁ: sucho, parameter podzemnej vody, čiara prekročenia, metóda hraničnej hodnoty, normalizovaný index závažnosti sucha v podzemnom odtoku, povodie toku Nitra.

\section{Introduction}

Hydrological drought is being broadly studied within last decades in many countries. It is because of increasing frequency of drought periods occurrence also in mild climate conditions. The increasing air temperature, often combined with the lack of precipitation is manifesting in decreasing of available water amounts in river basins, among them also in groundwater. There were many studies done devoted to drought. Processes and estimation methods for surface and groundwater drought were ana- lyzed by Tallaksen and van Lanen Eds. (2004), inter-comparison of circulation patterns and drought occurrence was done by Fleig et al. (2010). Regional characteristics of meteorological and hydrological droughts were proposed and summarized by Hisdal and Tallaksen (2003). Streamflow trends in the Europe were studied by Stahl et al. (2010); Kliment et al. (2011). Hisdal et al. (2001) paid their attention to streamflow drought severity changes in Europe. Drought occurrence in Nordic countries was analyzed by Wilson et al. (2010), the most severe droughts in UK since 1976 were described and 
analyzed by Marsh et al. (2007). National procedure for low flow estimation in Austria was proposed by Laaha and Bloeschl (2007), low flow regionalization for southwest Germany was done by Schreiber and Demuth (1997). Space-time modeling of catchment scale drought characteristics was published by Tallaksen et al. (2009). Winter drought in Europe was studied by van Loon et al. (2010); its occurrence in the upper Rhine area was analyzed by Pfister et al. (2006). Groundwater drought occurrence in Slovakia was studied by Fendeková and Ženišová, Eds., (2010), Machlica and Stojkovova (2008), Machlica et al. (2010), low flows in Slovakia were studied by Demeterová and Škoda (2009), seasonality of low flows in Slovakia was analyzed by Kohnova et al. (2009). Ecological aspects connected to drought occurrence in the upper part of the Torysa River catchment, Slovakia, were analyzed by Fendekova et al. (2011).

Groundwater drought can be expressed using several quantitative parameters of groundwater, such as groundwater runoff, spring yield, groundwater table value, groundwater recharge and others. Groundwater runoff is not measurable directly, except of spring yields measurements. In the hydrogeological practice, is substituted by the base flow values, derived from the discharge time series. After that, the groundwater drought analysis can be done, consisting of identification of drought periods occurrence, their length and severity, followed by the groundwater drought classification.

The paper is devoted to groundwater drought; the attention is paid to the base flow drought analysis and assessment in the Nitra River basin. Drought occurrence was estimated and classified, drought propagation downstream the Nitra River basin was analyzed. Differences in drought parameters in a small mountainous sub-basin and larger lowland sub-basins were discussed.

\section{Study area description}

Nitra River Basin is a sub-basin of the Váh River with the total area of $4,063.66 \mathrm{~km}^{2}$ up to Nové Zámky profile. The river flows in approximately north-south direction, the most important right-side tributaries are Nitrica and Bebrava, the most important left-side tributaries are represented by Handlovka and Žitava. All climatic-geographical types of climate occurring in the Slovak territory are present in the basin: warm through moderately warm up to cold, depending on the altitude (Land- scape atlas of SR, 2002). According to KöppenGeiger classification, the moderately warm, humid continental climate of the Dfb type is typical for the basin.

The mean altitude reaches $372 \mathrm{~m}$ a.m.s.l. with the lowest value of $108 \mathrm{~m}$ a.m.s.l. (closing profile of the basin) and the highest value of $1346 \mathrm{~m}$ a.m.s.l. (Mount Vtáčnik in Vtáčnik Mts.). The average annual areal precipitation amount was estimated on $696 \mathrm{~mm}$ for the long-term period of 1961 - 2000 (Danáčová et al., 2010). The annual runoff has a long-term value of $142 \mathrm{~mm}$, and the runoff coefficient has a value of 0.20 (Danáčová et al., 2010). The evapotranspiration reaches $554 \mathrm{~mm}$ in average; the mean yearly areal air temperature is $8.4^{\circ} \mathrm{C}$ (Danáčová et al., 2010). Values of all climatic elements are altitude-dependant.

Geological structure and hydrogeological settings in the headwater part differ importantly from those in the central and lower part of the basin. The upper part of the basin is bordered by mountain ranges of variegated geological structure and hydrogeological settings. Most of the mountains are built by crystalline core (Strážovské vrchy Mts. in the west, Malá Fatra Mts. in the north, Žiar Mts. in the east, Tribeč Mts. in the south-east), on which Mesozoic, mostly carbonatic complexes with the nappe structure are placed. In the eastern upper part of the basin, Vtáčnik Mts. is located, the eastern border in the central part of the basin is created by Pohronský Inovec Mts., both being products of the Neogene volcanism. The intra-mountainous depression of the Horná Nitra basin is filled by Palaeogene and Neogene sediments, in the area of Nováky and Handlová brown coal layers of the Neogene age occur. The upper-most layers covering the Neogene filling are built by fluvial sediments of Quaternary age consisting of loam, sand and gravel. The geological structure of the central and lower part of the basin is quite simple, flat, filled by Neogene sandy and clayey sediments, being covered by fluvial sediments. The highest amounts of groundwater are accumulated in Quaternary sediments of the Nitra River alluvial plain and its larger tributaries with the thickness up to 10 meters. Groundwater of alluvial plain is mostly hydraulically interconnected with surface streams. The influence of surface streams on groundwater level can be observed up to the distance of $100-300 \mathrm{~m}$, it ends up in the distance of $300-1000 \mathrm{~m}$ (Anon, 2000). Well yields reach up to $151 \mathrm{~s}^{-1}$ (Anon, 2000). 


\section{Material and methods}

Data from six discharge gauging profiles regularly observed in the Nitra River Basin were used in the study (Fig. 1, Tab. 1).

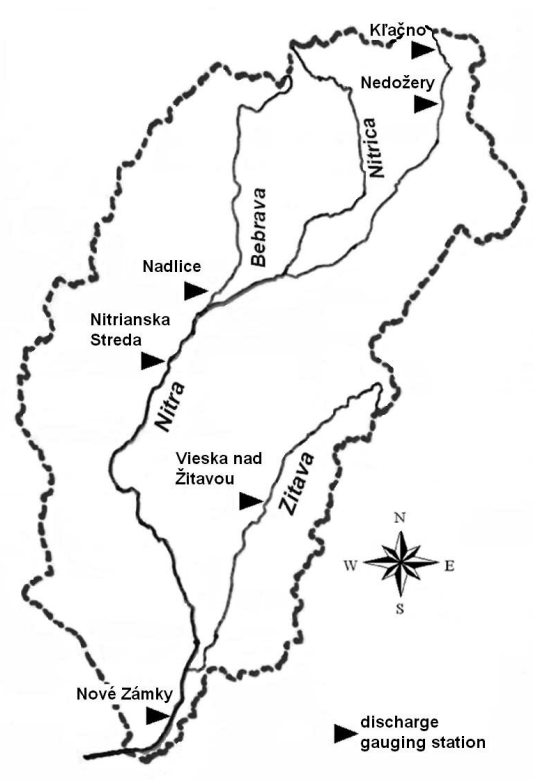

Fig. 1. Location of utilized gauging profiles.

Gauging profile in Kl'ačno represents a small sub-basin in the mountainous upper part of the basin, which is not influenced by human activities. Catchment area up to Nedožery profile is larger; the profile is located in the intra-mountainous depression of the Horná Nitra. One of the longest time series were at the disposal for Nedožery profile, having duration of more than 65 years. The profile in Nitrianska Streda represents the central part of the basin, and the Nové Zámky profile is the closing profile of the whole basin located at the place from which the Nitra River is artificially channeled to the Váh River. Both profiles represent the discharge influenced by various kinds of human activities as for instance regulation of discharges at water reservoir Nitrianske Rudno, dewatering of brown coal mines in Handlová and Nováky, water transfer from Nitrica to Nitra River sub-basin, irrigation and others. Two most important tributaries of Nitra River were also assessed. Nadlice profile represents the downstream profile of Bebrava River sub-basin; Vieska nad Žitavou profile represents the Žitava River sub-basin. Basic parameters of profiles are in Tab. 1. Because of inconsistency of discharge data in Nové Zámky profile, only the period of hydrological years of $1991-2006$ was used in the study.

The input data on daily discharges in all profiles (Tab. 1) were processed statistically, and then used in the program package HydroOffice 2010 (Gregor, 2008). The package enables:

- separation of the base flow from the average daily discharges using $\mathrm{BFI}+2$ sub-routine,

- calculation of the base flow duration curve parameters (cumulative frequency curve for the separated base flow) in FDC sub-routine (www.hydrooffice.org),

- utilization of base flow duration curve parameters as threshold levels for estimation of drought periods occurrence in TLM sub-routine (www.hydrooffice.org).

$\mathrm{T}$ a b $1 \mathrm{e}$ 1. Basic parameters of the discharge gauging profiles.

\begin{tabular}{lllll}
\hline Profile Number and Name & River & $\begin{array}{l}\text { Altitude } \\
{[\mathrm{m} \mathrm{a.m.s.1.]}]}\end{array}$ & $\begin{array}{l}\text { Area } \\
{\left[\mathrm{km}^{2}\right]}\end{array}$ & Years of observation \\
\hline 6500 Kl'ačno & Nitra & 471.84 & 10.50 & $1975-2006$ \\
6540 Nedožery & Nitra & 287.00 & 181.57 & $1941-2006$ \\
6710 Nadlice & Bebrava & 171.11 & 598.81 & $1941-2006$ \\
6730 Nitrianska Streda & Nitra & 158.25 & 2093.71 & $1973-2006$ \\
6820 Vieska nad Žitavou & Zitava & 154.14 & 295.46 & $1961-2006$ \\
6772 Nové Zámky & Nitra & 108.73 & 4063.66 & $1990-2006^{*}$ \\
\hline
\end{tabular}

*time series shortened due to changes in profile location

Sub-routine $\mathrm{BFI}+2$ is based on the original method of base flow (BF) separation from the average daily discharges (BFI model), which was developed in the Institute of Hydrology (1980). N-day consecutive and non-overlapping periods are used for calculation of minimal discharges which represent turning points on the base flow hydrogram.
The original program calculated with the fixed $\mathrm{N}$ value, equal to 5 days. Application of the original BFI model on Slovak conditions gave much higher base flow values than other methods usually utilized in Slovak hydrogeological practice. The innovation of the original program consists in possibility to choose the length of the $\mathrm{N}$ value. The new 
calculation algorithm also implements the suggestion of Tallaksen and van Lanen Eds. (2004) and some other methods for base flow separation based on recursive filters. The value of $N$ equal to 15 or 30 days gives the best values (depending on hydrogeological settings), as confirmed by Machlica
(2010). An example of the results of base flow separation for Nedožery profile is in Fig. 2. Discharges larger than ten cubic meters per second were cut in the figure, in order to make the base flow separation more distinct.

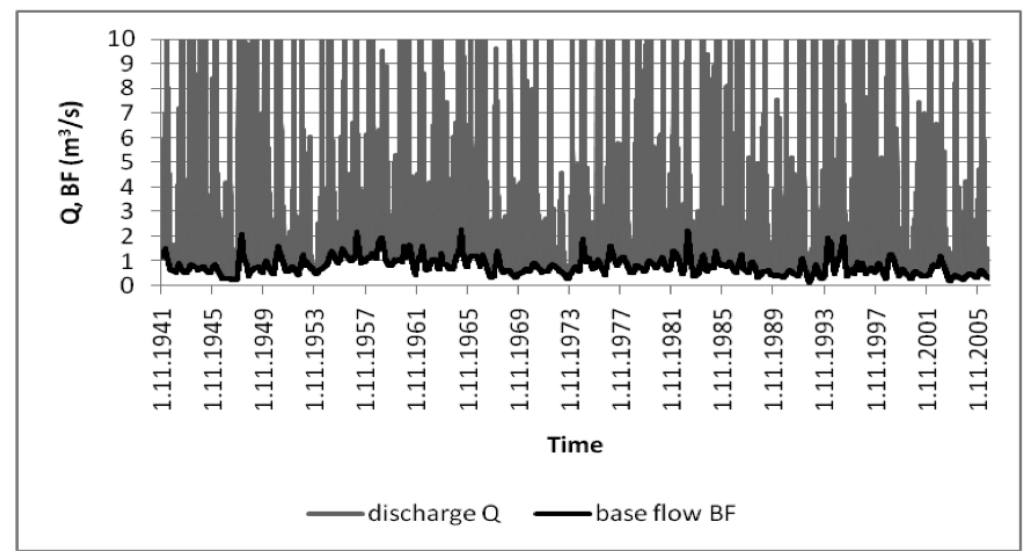

Fig. 2. Base flow separation from discharges for Nedožery profile.

Separated values of the base flow, representing groundwater runoff from the catchment, were statistically processed. Obtained statistical parameters were compared with those estimated for the original average daily discharge time series.

Base flow values were then used for calculation of the average long-term base flow from the basin. The long-term average value was used as a comparative value during the process of the base flow drought extremity assessment.

Respective years on the low base flow side were classified as years with:

- extremely low base flow in the case when the average yearly base flow was lower than $70 \%$ of the long-term average,

- very low base flow in the case when the average yearly base flow ranged in the interval of $70 \%$ to $80 \%$ of the long-term average,

- low base flow in the case when the average yearly base flow ranged in the interval of $80 \%$ to $90 \%$ of the long-term average.

Years with the base flow value higher than $90 \%$ of the long-term average were classified as normal $(90-110 \%)$. Accordingly, years with the high $(110-120 \%)$, very high $(120-130 \%)$ and extremely high (more than $130 \%$ ) base flow were also defined.

Drought occurrence was evaluated using the threshold level method (Stahl, 2001; Tallaksen, van Lanen, Eds., 2004). Threshold level values were calculated using the TLM 2.1 sub-routine, which is a part of the HydroOffice 2010 package (Gregor, 2008). Base flow duration curves were constructed for each hydrological year of the whole evaluated period, after that the master base flow duration curve was constructed using the average values of respective percentiles. The base flow value of $\mathrm{BF}_{90 \mathrm{mc}}$ calculated from the master base flow duration curve was used as the base flow drought threshold level value in further analysis of the base flow drought.

Value of the $\mathrm{BF}_{90 \mathrm{mc}}$ represents approximately 330-day long-term average base flow. An example of the master base flow duration curve construction for the Nedožery gauging profile is in Fig. 3. According to base flow values in the range of $\mathrm{BF}_{90 \mathrm{mc}}$ to $\mathrm{BF}_{97 \mathrm{mc}}$, the years 1956 and 1957 belonged to wet years, years 1992, 1994, 2003 and 2004 were dry.

The long-term base flow duration curve was also constructed using the long-term time series of the base flow values. The comparison of both - master base flow duration curve and long-term base flow duration curve values was done.

Base flow drought extremity was assessed using two methods. In the first one, the base flow drought was classified using the $\mathrm{BF}_{90 \mathrm{mc}}, \mathrm{BF}_{80 \mathrm{mc}}$ and $\mathrm{BF}_{70 \mathrm{mc}}$. Occurrence of dry periods was evaluated also from the point of view of their duration and categorization according to the season of the year. Drought periods shorter than 10 days were not assessed. Pooling of consequent droughts was done for each 
two droughts which were separated by not more than two days with discharges exceeding the threshold level value. Drought periods longer than 10 days were classified into three categories: with the duration (D) $10-49$ days, 50 - 99 days and 100 and more days (Fendeková, Ženišová, Eds., 2010). Seasons were defined for the base flow drought classification as follows: Sp: spring season (MarchMay), S: summer season (June-August), A: autumn season (September-November) and W: winter season (December-February). A multiyear drought occurred when the drought lasted for more than 365 days, or from one season of the previous year to the same season of the next year. The classification scheme was as follows:

- extreme base flow drought occurred when the average daily discharge did not reach the value of $B F_{90 \mathrm{mc}}$,

- medium base flow drought occurred when the average daily discharge varied in the range $\mathrm{BF}_{90 \mathrm{mc}}-B F_{80 \mathrm{mc}}$

- weak base flow drought occurred when the average daily discharge varied in the range $\mathrm{BF}_{80 \mathrm{mc}}-$ $B F_{70 \mathrm{mc}}$,

- discharges with the value higher than $B F_{70 \mathrm{mc}}$ indicated no base flow drought.

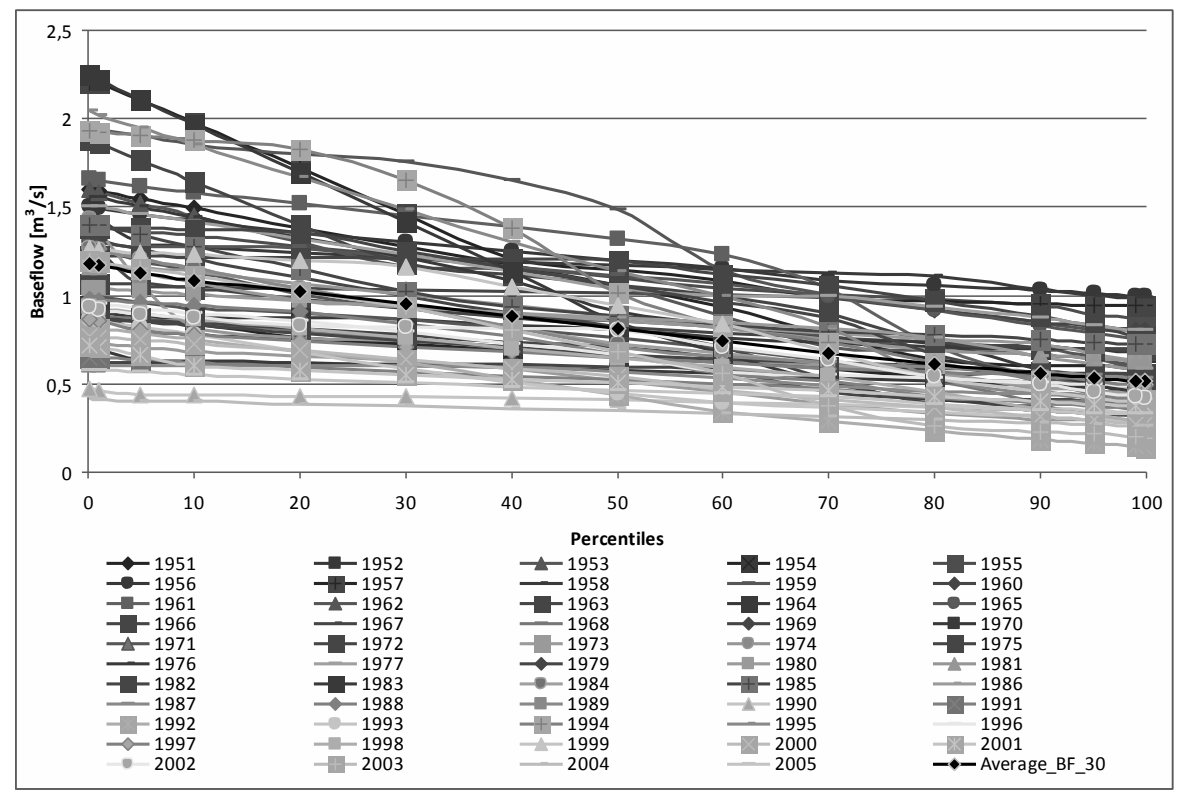

Fig. 3. Construction of the master base flow curve for Nedožery profile.

Such a classification is in accordance with the classification of year wetness applied on discharges and precipitation (Majerčáková et al., 2007).

Another possibility to classify the base flow drought gives the Sequent Peak Algorithm method (SPA method), which enables to estimate not only the beginning and ending date of the drought, and its duration, but also the deficit volume during the drought period using the threshold level value. The $B F_{90 \mathrm{mc}}$ value was used as the threshold level. At present, value of the 80 -th percentile $\left(B F_{80 \mathrm{mc}}\right)$ becomes more often to be used as the threshold value. However, in such case, more droughts of shorter duration are estimated, which often do not cover larger areas. Therefore, the threshold value of the 90-th percentile $\left(B F_{90 \mathrm{mc}}\right)$ was used in the study, detecting more severe droughts covering larger areas.
Drought severity index was calculated as the ratio of the total deficit volume (in respective drought period) and the drought period duration. In the end, value of the drought severity index was divided by the individual average long-term base flow value in the respective profile, receiving the standardized base flow drought severity index. Calculation of the standardized index enabled to compare the base flow drought severity in different sub-basins.

\section{Results and discussion}

Results of basic statistical evaluation of the average daily discharges and base flow values for the Nedožery gauging profile are given in Tab. 2 as an example of the input data statistical evaluation. 
T a b 1 e 2. Basic statistical evaluation of discharges and base flow values (1941-2006).

\begin{tabular}{lcccccccccccc}
\hline Value & $N$ & $x_{\text {aver }}$ & $x_{\text {med }}$ & $x_{\bmod }$ & $x_{\max }$ & $x_{\min }$ & $s_{x}$ & $C_{V}$ & $C_{S}$ & $C_{S s t}$ & $E$ & $E_{s t}$ \\
\hline Discharge & 23741 & 2.13 & 1.33 & 0.7 & 62.8 & 0.14 & 2.54 & 119.1 & 5.07 & 303 & 50.4 & 1585 \\
Base flow & 23741 & 1.32 & 1.08 & 0.7 & 8.9 & 0.14 & 0.92 & 70.0 & 2.32 & 146 & 8.23 & 259 \\
\hline
\end{tabular}

Values of input data count $(N)$, arithmetic mean $\left(x_{\text {aver }}\right)$, median $\left(x_{\text {med }}\right)$, modus $\left(x_{\text {mod }}\right)$, maximum $\left(x_{\max }\right)$, minimum $\left(x_{\min }\right)$, standard deviation $\left(s_{x}\right)$, coefficient of variation $\left(C_{V}\right)$, skewness $\left(C_{S}\right)$, standardized skewness $\left(C_{S s t}\right)$, kurtosis $(E)$ and standardized kurtosis $\left(E_{s t}\right)$ were calculated.

The results show that the frequency distribution of both variables is strongly asymmetric (skew), but the measure of asymmetry represented by the ratio of $x_{\text {aver }}: x_{\text {med }}: x_{\text {mod }}$, as well as by values of $C_{S}$ and $C_{S s t}$ is lower for the base flow in comparison with the original discharge values. The variability of base flow values ensemble expressed by standard deviation and coefficient of variation also decreased from $\mathrm{C}_{\mathrm{V}}$ equal to $119 \%$ by discharges to 70 $\%$ for the base flow ensemble. Anyway, the ensemble still does not have the normal frequency distribution, which is documented by values of $C_{S s t}$ and $E_{s t}$.

Comparison of percentiles obtained from the master base flow duration curve $\left(B F_{m c}\right)$ and the average base flow duration curve for the long-term base flow time series $\left(B F_{\mathrm{l}-t}\right)$ showed that the values of $B F_{m c}$ are higher than the values of $B F_{1-t}$. The differences are the highest at the highest percentiles and decrease towards the median value. Comparison of selected percentiles obtained for base flow values at Nedožery profile for the period 1951 -2005 is in Tab. 3. Therefore, it is necessary to give the information, which procedure was used for base flow duration curve construction. The authors prefer to use the master base flow duration curve, which is not biased by cumulating of low values in the lower tail of the curve $\left(80^{\text {th }}-99^{\text {th }}\right.$ percentile $)$, as it is in the case of the average base flow duration curve.

Dry years according to base flow value were classified using the ratio of the average yearly base flow $(B F Y)$ on the long-term base flow value ( $B F$ $A$ ). Classification of dry years in Nedožery profile is in Fig. 4.

$\mathrm{T}$ a b 1 e 3. Comparison of master and long-term base flow duration curve values.

\begin{tabular}{llllll}
\hline Value & $B F_{50}$ & $B F_{70}$ & $B F_{80}$ & $B F_{90}$ & $B F_{95}$ \\
\hline Master base flow duration curve & 0.815 & 0.677 & 0.609 & 0.559 & 0.536 \\
Long-term base flow duration curve & 0.767 & 0.600 & 0.520 & 0.409 & 0.362 \\
\hline
\end{tabular}

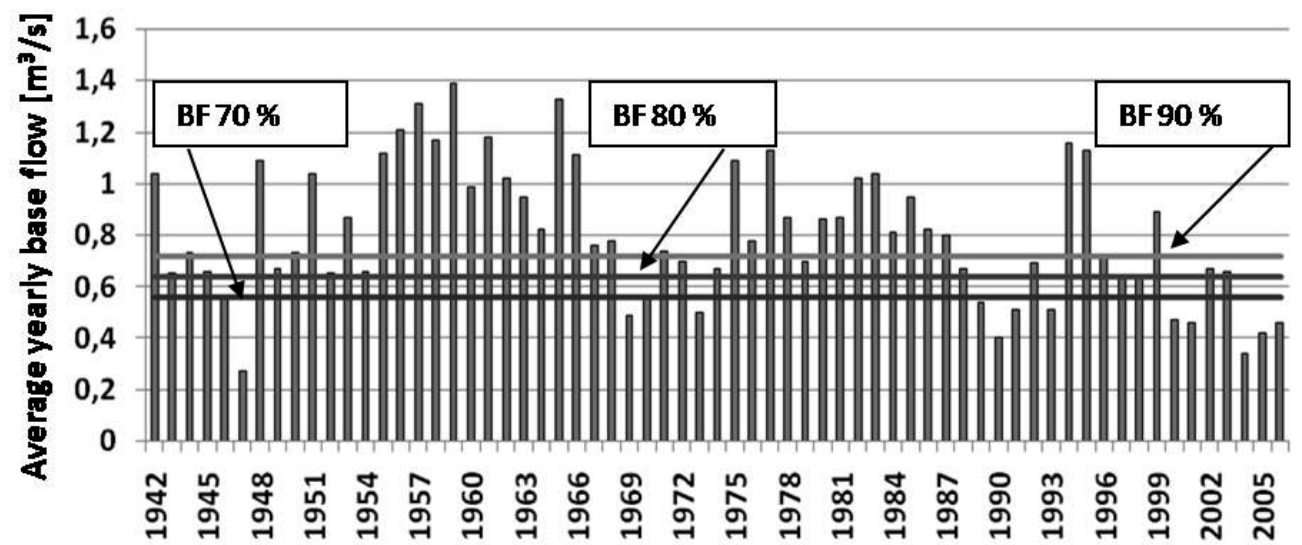

Fig. 4. Evaluation of dry years in the base flow values for Nedozery profile.

It can be seen in Fig. 4 that extremely low base flow occurred in the profile in 1946 and 1947 , 1969 and 1970, 1973, 1989 to 1991, 1993, 2000 and 2001, as well as 2004 to 2006. Tab. 4 shows number of dry years according to base flow classification, expressed in absolute numbers, and as 
percentage of the total number of processed years for all evaluated profiles.

Tab. 4 also shows that the dry years occur more often in the upper - mountainous part of the basin in comparison with the central and downstream part. This is valid not only for the common period of 1976 - 2006 in five of six evaluated profiles (except of Nové Zámky), but also for the 1991 -2006 period (16 years), in which all six profiles were assessed. Years with the extremely low base flow prevailed in the upper part of the basin, on the other hand, the low and normal to extremely high base flow was more frequent in the central part of the basin (profile Nitrianska Streda). Only in Nové Zámky profile, the number of years with normal to extremely high base flow was higher than number of years with one of the low base flow categories.

Occurrence of dry periods was evaluated also from the point of view of their duration $(D)$. The results in Tab. 5 show that longer droughts (100 days and more) prevail in the basin.

$\mathrm{T}$ a b 1 e 4 . Number of base flow periods below normal.

\begin{tabular}{|c|c|c|c|c|c|c|}
\hline \multirow[b]{2}{*}{ Profile } & & \multicolumn{5}{|c|}{ Base flow } \\
\hline & & $\begin{array}{c}\text { Extremely low } \\
\text { (EL) }\end{array}$ & $\begin{array}{l}\text { Very low } \\
\text { (VL) }\end{array}$ & $\begin{array}{l}\text { Low } \\
\text { (L) }\end{array}$ & $\begin{array}{c}\text { Total low } \\
(\mathrm{EL}+\mathrm{VL}+\mathrm{L})\end{array}$ & $\begin{array}{c}\text { Normal to } \\
\text { extremely } \\
\text { high }\end{array}$ \\
\hline \multirow[t]{2}{*}{ Kl’ačno } & $1976-2006$ & 10 & 1 & 3 & 14 & $17(55 \%)$ \\
\hline & $1991-2006$ & $9(56 \%)$ & $1(6 \%)$ & $3(19 \%)$ & 13 & $3(19 \%)$ \\
\hline \multirow[t]{3}{*}{ Nedožery } & $1942-2006$ & 14 & 2 & 13 & 29 & $36(55 \%)$ \\
\hline & $1991-2006$ & 9 & 2 & 6 & 17 & $14(45 \%)$ \\
\hline & $1976-2006$ & $7(43.5 \%)$ & $2(12.5 \%)$ & $4(25 \%)$ & 13 & $3(19 \%)$ \\
\hline \multirow[t]{3}{*}{ Nadlice } & $1942-2006$ & 12 & 7 & 11 & 30 & $34(52 \%)$ \\
\hline & $1991-2006$ & 8 & 5 & 8 & 21 & $10(32 \%)$ \\
\hline & $1976-2006$ & $6(37.5 \%)$ & $3(18.7 \%)$ & $5(31 \%)$ & 14 & $2(12.5 \%)$ \\
\hline Vieska n. & $1962-2006$ & 5 & 5 & 12 & 22 & $23(51 \%)$ \\
\hline \multirow{2}{*}{ Žitavou } & $1991-2006$ & 4 & 2 & 8 & 14 & $17(55 \%)$ \\
\hline & $1976-2006$ & $2(4.4 \%)$ & $2(6.4 \%)$ & $5(31.3)$ & 9 & $7(44 \%)$ \\
\hline Nitrianska & $1976-2006$ & 2 & 3 & 8 & 13 & $18(58 \%)$ \\
\hline Streda & $1991-2006$ & $2(12.5 \%)$ & $3(19 \%)$ & $6(37.5 \%)$ & 11 & $5(31 \%)$ \\
\hline Nové Zámky & $1991-2006$ & $3(19 \%)$ & $2(12.5 \%)$ & $2(12.5 \%)$ & 7 & $9(56 \%)$ \\
\hline
\end{tabular}

T a b 1 e 5. Number of base flow drought periods of respective duration.

\begin{tabular}{|c|c|c|c|c|c|c|}
\hline Profile & & $\begin{array}{c}\text { Number of } \\
\text { periods } \\
D: 10-49 \\
\text { days } \\
\end{array}$ & $\begin{array}{c}\text { Number of } \\
\text { periods } \\
D: 50-100 \\
\text { days }\end{array}$ & $\begin{array}{l}\text { Number of } \\
\text { periods } \\
D: 100 \text { days } \\
\text { and more }\end{array}$ & $\begin{array}{c}\text { Total } \\
\text { number of } \\
\text { periods }\end{array}$ & $\begin{array}{c}\text { Total } \\
\text { duration }\end{array}$ \\
\hline \multirow[t]{2}{*}{ Kl'ačno } & $1976-2006$ & 2 & 1 & 5 & 8 & 1723 \\
\hline & $1991-2006$ & 2 & 1 & 5 & 8 & 1723 \\
\hline \multirow[t]{3}{*}{ Nedožery } & $1941-2006$ & 3 & 2 & 13 & 18 & 2910 \\
\hline & $1991-2006$ & 3 & 2 & 9 & 14 & 2023 \\
\hline & $1976-2006$ & 2 & 1 & 8 & 11 & 1667 \\
\hline \multirow[t]{3}{*}{ Nadlice } & $1941-2006$ & 2 & 2 & 11 & 15 & 3482 \\
\hline & $1991-2006$ & 2 & 2 & 8 & 12 & 2723 \\
\hline & $1976-2006$ & 0 & 2 & 5 & 7 & 1837 \\
\hline \multirow[t]{3}{*}{ Vieska n. Žitavou } & $1941-2006$ & 3 & 4 & 10 & 17 & 2677 \\
\hline & $1991-2006$ & 1 & 2 & 5 & 8 & 1485 \\
\hline & $1976-2006$ & 1 & 2 & 3 & 6 & 1116 \\
\hline \multirow[t]{2}{*}{ Nitrianska Streda } & $1971-2006$ & 2 & 4 & 5 & 11 & 2024 \\
\hline & $1991-2006$ & 1 & 2 & 4 & 7 & 1665 \\
\hline Nové Zámky & $1991-2006$ & 1 & 1 & 3 & 5 & 924 \\
\hline
\end{tabular}

The frequency of drought periods, as well as total duration of droughts is higher in the upper mountainous part of the basin. Long droughts occurred in the whole basin in 1991 - 1994. The longest drought in the observed period occurred in the same period in Nadlice profile; lasting for 1062 days. The next base flow drought covering the whole basin was the 2003 - 2004 drought, which in the Nitrianska Streda profile lasted till the beginning of 2005.

The comparison of the drought severity in respective sub-basins according to standardized base 
flow drought severity index for the common period of 1991 - 2006 was done. Only the most severe droughts in each respective profile are showed in Tab. 6.

In this period, the most severe drought according to standardized base flow drought index occurred in Nadlice profile in the years 1991 - 1994. The most severe drought in the Nitrianska Streda profile was divided into two sub-periods, the first one occurred in 1990 - 1991 (lasting for 182 days) with the index value of 62.8 , being followed within a few months with the second one in $1991-1993$ period with the value of 53.1 and lasting for 566 days. However, the most severe drought in the basin during the whole observed period occurred in Vieska nad Žitavou profile in 1962 - 1963 with the standardized base flow drought severity index of 159.6 (lasting for 313 days) and in Nedožery profile in $1946-1948$ with the index value of 127.6 (lasting for 564 days).

T a b 1 e 6. The most severe droughts in evaluated profiles in the period $1990-2006$.

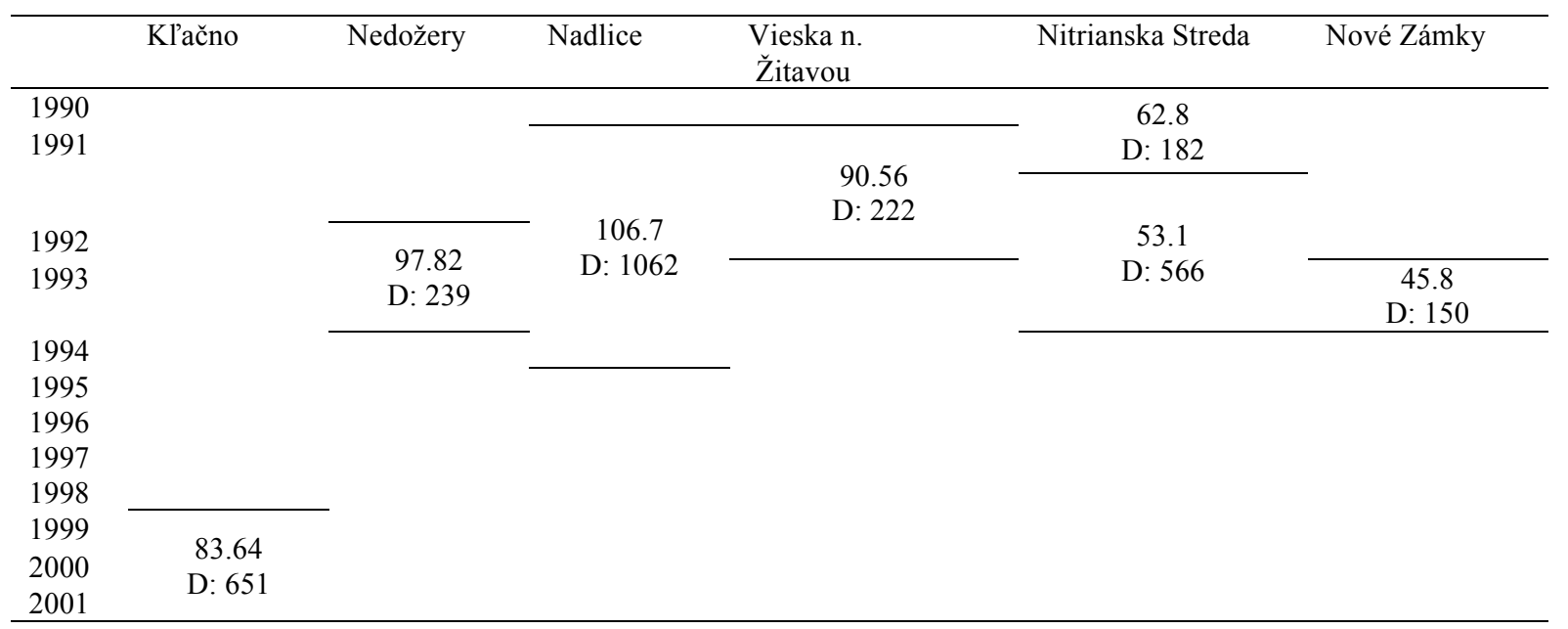

What the drought seasonality is concerned, in the upper part as well as in the central part of the basin, the summer-autumn and summer-winter droughts have approximately the same occurrence frequency. In the lowest profile at Nové Zámky, the summer autumn drought prevails and in the highest profile at Kl'ačno, the spring-winter drought was the most frequent.

When comparing the frequency of drought periods and their total length in the base flow with the discharge drought occurrence in the same profiles, it was documented by Fendeková and Fendek (2011) that discharge drought is more frequent, but lasts shorter - droughts with the duration of $10-49$ days prevail. According to the same authors (Fendeková, Fendek, 2011), drought in the groundwater heads occurred two-times more frequently in the upper part of the basin, but it lasted shorter as in the lowland part.

\section{Conclusion}

Drought as one of the more frequently occurring phenomenon can be accessed from different points of view using various characteristics. Such disparateness is followed by more and more drought indices occurring in the literature. Authors of this paper evaluated the drought in a yearly scale. The standardized base flow drought severity index was proposed for base flow drought characterization. It was documented that years with the extremely low base flow occur much often in the mountainous part of the Nitra River Basin than in the lowland part. Similarly, differences in seasonality and base flow drought duration between the upper, central and downstream part of the basin were showed. As it follows from the most severe droughts occurrence analysis, there is no unified pattern of the drought occurrence in the Nitra River basin. It was confirmed that the upper part of the basin is more sensitive on extreme climatic situation occurrence leading to drought in surface and groundwater.

Acknowledgment. The authors would like to thank to FP6 Watch project (contract Number 036946), from which financial sources the research was supported. 


\section{REFERENCES}

ANON 2000: Hydroekologický plán povodia Nitry v úseku od prameňa po zaústenie preložky Nitry. Čast' A. Slovenský vodohospodársky podnik š. p. Banská Štiavnica, 163 s. a prílohy.

DANÁČOVÁ Z., GÁPELOVÁ V., LOVÁSOVÁ L., L'UPTÁK L., MELOVÁ K., PODOLINSKÁ J., RISCHANEKOVÁ M., SÍČOVÁ B., STAŇOVÁ J., 2010: Vodohospodárska bilancia množstva povrchových vôd za rok 2009. SHMÚ Bratislava, $320 \mathrm{~s}$.

DEMETEROVÁ B., ŠKODA P., 2009: Malá vodnost' vybraných tokov Slovenska. J. Hydrol. Hydromech., 57, 1, 55-69.

FENDEKOVÁ M., FENDEK, M., 2011: Typy a hodnotenie sucha $\mathrm{v}$ povrchových a podzemných vodách v povodí Nitry. In: Hydrologie malého povodí. Díl I. Praha, Ústav hydrologie a hydrauliky AV ČR, 2011. s. 71-77.

FENDEKOVÁ M., ŽENIŠOVÁ Z. (Eds.), 2010: Hydrogeologické sucho. Bratislava, SAH, 2010. 190 s. ISBN 978-80969342-7-0.

FENDEKOVA M., DEMETEROVA B., SLIVOVA V., MACURA V., FENDEK M., MACHLICA A., GREGOR M., JALCOVIKOVA M., 2011: Surface and groundwater drought evaluation with respect to aquatic habitat quality applied in Torysa river catchment, Slovakia. Ecology \& Hydrobiology, 11,1-2, 49-61.

FLEIG A. K., TALLAKSEN L. M., HISDAL H., STAHL K., HANNAH D. M., 2010: Inter-comparison of weather and circulation type classifications for hydrological drought development. Physics and Chemistry of the Earth, 35, 507-515 .

GREGOR M., 2008: Vývoj programov na analýzu časových radov výdatností prameňov a prietokov vodných tokov. Podzemná voda, XIV , 2, 189-198.

HISDAL H., TALLAKSEN L. M., 2003: Estimation of regional meteorological and hydrological drought characteristics. J. Hydrol., 281, 3, 230-247.

HISDAL H., STAHL K., TALLAKSEN L.M., DEMUTH S., 2001: Have streamflow droughts in Europe become more severe or frequent? Int. J. Climatol., 21, 317-333.

INSTITUTE OF HYDROLOGY, 1980: Low flow studies. Res. Rep. 1, Institute of Hydrology, Wallingford, UK.

KLIMENT Z., MATOUSKOVA M., LEDVINKA O., KRALOVEC V., 2011: Trend analysis of rainfall-runoff regimes in selected headwater areas of the Czech Republic. J. Hydrol. Hydromech., 59, 1, p. 36-50.

KOHNOVA S., HLAVCOVA K., SZOLGAY J., STEVKOVA A., 2009: Seasonality analysis of the occurrence of low flows in Slovakia. International Symposium on Water Management and Hydraulic Engineering, Ohrid/Macedonia, 1-5 September 2009, 711-719.

LAAHA G., BLOESCHL G., 2007: A national low flow estimation procedure for Austria. Hydrological Science J., 52, 4, 625-644.

LANDSCAPE ATLAS OF THE SLOVAK REPUBLIC: 2002, 1st. Edition. Ministerstvo životného prostredia SR, Bratislava; Slovenská agentúra životného prostredia, Banská Bystrica, 344 s. ISBN 80-88833-27-2
LOON A. F. VAN, LANEN H. A. J. VAN, HISDAL H., TALLAKSEN L. M., FENDEKOVA M., OOSTERWIJK J., HORVAT O., MACHLICA A., 2010: Understanding hydrological winter drought in Europe. IAHS Publication; 340: Global Change: Facing Risks and Treats to Water Resources. IAHS Press, Oxfordshire, 189-197.

MACHLICA A., 2010: Groundwater runoff modelling. PhD. Thesis, Faculty of Natural Sciences, Comenius University in Bratislava.

MACHLICA A., FENDEKOVA M., FENDEK M., 2010: Modelling of groundwater runoff parameters developments in different geological conditions. Acta Geologica Slovaca (AGEOS), 2, 2, 103-112.

MACHLICA A., STOJKOVOVÁ M., 2008: Groundwater drought in different geological conditions. XXIVth Conference of Danubian countries, IOP Publishing. IOP Conf. Ser.: Earth Environ. Sci., 4, 01210, doi: 10.1088/17551307/4/1/012010

MAJERČÁKOVÁ O., ŠKODA P., DANÁČOVÁ Z., 2007: Selected hydrological and precipitation characteristics of $1961-2000$ and $2000-2006$ periods in the High Tatra region. Meteorological J., 14, 4, 205-210.

MARSH T., COLE G., WILBY R., 2007: Major droughts in England and Wales, 1800-2006, Weather, 62, 4, 87-93.

PFISTER C., WEINGARTNER R., LUTENBACHER J., 2006: Hydrological winter droughts over the last 450 years in the Upper Rhine basin: a methodological approach. Hydrol. Sci. J., 51, 5, 966-985.

SCHREIBER P., DEMUTH S., 1997: Regionalisation of low flows in southwest Germany. Hydrol. Sci. J., 42, 6, 845-858 .

STAHL K., 2001: Hydrological drought - a study accross Europe. PhD. Thesis Albert-Ludwigs Universitat Freiburg, Freiburger Schriften zur Hydrologie no. 15, Freiburg, Germany.

STAHL K., HISDAL H., HANNAFORD J., TALLAKSEN L.M., VAN LANEN H.A.J., SAUQUET E., DEMUTH S., FENDEKOVÁ M., JÓDAR J., 2010: Streamflow trends in Europe: evidence from a dataset of near-natural catchments. Hydrology and Earth System Sciences, 14, 12, 2367-2382.

TALLAKSEN L. M., VAN LANEN H. A. J. (Eds.), 2004: Hydrological drought: processes and estimation methods for streamflow and groundwater. Developments in water science; 48, The Netherlands, Amsterdam: Elsevier Science, pp. 579, ISBN 0-444-51688-3.

TALLAKSEN L. M., HISDAL H., VAN LANEN H. A. J., 2009: Space-time modeling of catchment scale drought characteristics. J. Hydrol., 375, 363-372.

WILSON D., HISDAL H., LAWRENCE D., 2010. Has streamflows changed in the Nordic countries? - Recent trends and comparison to hydrological projections. J. Hydrol., 394, 334-346.

www.hydrooffice.org (march 2012)

Received 23 August 2011 Accepted 13 March 2012 